\title{
Eleições e Democracia no Brasil: Victor Nunes Leal e a Transição de $1945^{*}$
}

\section{Fernando Limongi}

Professor titular da Universidade de São Paulo (USP) e pesquisador sênior do Centro Brasileiro de Análise e Planejamento (Cebrap) e coordenador do Núcleo de Estudos Comparados e Internacionais (NECI) da mesma universidade. E-mail: fdmplimo@usp.br.

\begin{abstract}
A eleição de 1945 marca o início da primeira experiência democrátiA ca do Brasil. Eleição, por si só, não é condição suficiente para qualificar o regime nascente como democrático. Eleições não eram novidade na história política do Brasil, afinal, direta ou indiretamente, governantes foram eleitos por mais de cem anos, de 1822 até 1930. Ainda assim, há uma ruptura em 1945; eleições passam a ser competitivas. Há uma mudança na natureza do processo eleitoral; o governo perde o controle que sempre tivera sobre o processo eleitoral. Por quê? O que havia mudado no país para que esta alteração tivesse lugar?
\end{abstract}

Em geral, a literatura nacional não enfrenta esta questão. Há, por certo, referências ao longo processo de modernização desencadeado pela Revolução de 1930, por meio do qual são criadas as condições necessárias à vigência de um regime democrático. Nesse tipo de análise, os planos socioeconômico e institucional se combinam. Assim, a criação da Justi-

\footnotetext{
* O texto foi escrito e desenvolvido no interior do Projeto Temático "Padrões de interação Executivo-Legislativo" e do Centro de Estudos da Metrópole (Cepid), ambos financiados pela Fundação de Amparo à Pesquisa do Estado de São Paulo (Fapesp). Além destes financiamentos e projetos, o autor contou ainda com bolsa individual de produtividade em pesquisas do Conselho Nacional de Desenvolvimento Científico e Tecnológico (CNPq) e com recursos da Pró-Reitoria de Pesquisa da Universidade de São Paulo (USP) ao Núcleo de Estudos Comparados e Internacionais (NECI). Agradeço os comentários de Marta Arretche, Rogério Arantes e Argelina Figueiredo à primeira versão do texto, que muito contribuíram para sua melhora. Os erros e confusões que permanecem são de minha responsabilidade.
}

DADOS - Revista de Ciências Sociais, Rio de Janeiro, vol. 55, no 1, 2012, pp. 37 a 69. 
ça Eleitoral, por exemplo, passa a ser vista como parte deste amplo processo de transformação estrutural da sociedade. Sob esta lente analítica, a ruptura verificada em 1945, quando notada, acaba sendo minimizada. Ironicamente, o trabalho seminal sobre a transição do Estado Novo à Democracia de 1946, o brilhante estudo de Maria do Carmo Campello de Souza ${ }^{1}$, frisa a continuidade entre os dois períodos, minimizando, implicitamente, a novidade.

Victor Nunes Leal é um dos poucos autores a enfatizar e problematizar a ruptura verificada em 1945. Sua obra é usualmente lida para dar conta dos vícios das práticas eleitorais vigentes no Império e, sobretudo, na Primeira República. Os comentários esparsos contidos na obra sobre o período que segue à queda do Estado Novo raramente merecem menção ${ }^{2}$. Contudo, por limitados que sejam, tais comentários são essenciais para o entendimento da obra e de suas proposições centrais. Uma explicação consistente das razões que levam à deformação do governo representativo pede que se explicitem as condições em que este funciona adequadamente. Por isto mesmo, por laterais e localizados que sejam, os comentários sobre o regime nascente são cruciais para o argumento contido no livro. E, quando lido desta forma, Coronelismo, Enxada e Voto ganha maior relevância e atualidade. Dito de forma direta, o livro permite distinguir a história eleitoral do país e dois grandes períodos em que a eleição de 1945 funcionaria como o divisor de águas, o período em que eleições não eram e o em que se tornaram competitivas.

Neste texto, retorno a Coronelismo, Enxada e Voto para discutir a evolução do governo representativo no Brasil. Mais especificamente, pretendo retomar um velho debate, a saber, o das condições necessárias para a vigência do governo democrático. Meu objetivo não é oferecer uma leitura alternativa ou uma nova interpretação da obra, mas simplesmente usar as reflexões ali contidas como ponto de partida para entender as transformações no processo eleitoral que levaram à emergência da democracia ${ }^{3}$. Busco identificar as explicações causais contidas na obra para perguntas específicas, provavelmente menos abrangentes do que as enfrentadas pelo autor e pela maioria de seus comentadores. Dito de forma direta, a preocupação central que estrutura o texto diz respeito às condições que permitem que eleições ganhem contornos competitivos, isto é, quando o governo pode vir a ser derrotado nas urnas. 
O texto está organizado da seguinte forma: a seção dois reconstitui o argumento central de Nunes Leal para tratar da deturpação do mecanismo representativo no Brasil durante o Império e a Primeira República. Nela, ressalto a ênfase dada pelo autor à estrutura agrária herdada do período colonial. Neste argumento, eleitores independentes são vistos como a precondição para o funcionamento adequado do governo representativo. Concluo essa seção mostrando a insuficiência de tal argumento, como ele é incapaz de dar conta da ruptura de 1945. A terceira seção toma o "governismo", uma das muitas facetas do "falseamento do governo representativo", como o principal e mais relevante fenômeno a ser explicado. O que há por explicar é o fato de o governo não perder eleições locais, estaduais e nacionais. Como procuro mostrar, na explicação oferecida pelo próprio Nunes Leal, a estrutura agrária e o voto de cabresto não têm papel de relevo. $\mathrm{O}$ amesquinhamento do município, sua falta de autonomia legal e financeira, é a variável crucial para explicar o governismo dos coronéis. A quarta seção apoia-se nesta constatação para discutir as bases da democratização de 1945. Busco em Nunes Leal a explicação para a ruptura que aquela conjuntura representou na história eleitoral do país. O texto é fechado com as conclusões, nas quais ressalto a originalidade e a importância da obra de Nunes Leal para o entendimento das eleições, sustentando que esta contribuição não se limita ao entendimento do caso brasileiro.

\section{GRANDE PROPRIEDADE E VOTO DE CABRESTO}

A grande propriedade é responsável pelo falseamento do governo representativo no Brasil. Esta afirmação pode ser encontrada em inúmeras passagens de Coronelismo, Enxada e Voto. Nunes Leal não se cansa de assinalar que, enquanto a estrutura agrária herdada do período colonial perdurar, todos os esforços para sanar os defeitos comumente identificados nas práticas e costumes políticos do país estarão fadados ao fracasso.

A razão é simples e direta: a pobreza do trabalhador rural e sua dependência para com o proprietário de terra. As carências materiais e cognitivas do trabalhador conjugam-se com o seu isolamento. $\mathrm{O}$ argumento de Nunes Leal (1975:25) é cristalino:

Completamente analfabeto, ou quase, sem assistência médica, não lendo jornais, nem revistas, nas quais se limita a ver as figuras, o trabalhador rural, a não ser em casos esporádicos, tem o patrão na conta de ben- 
feitor. E é dele, na verdade, que recebe os únicos favores que sua obscura existência conhece. Em sua situação, seria ilusório pretender que esse novo pária tivesse consciência do seu direito a uma vida melhor e lutasse por ele com independência cívica. O lógico é o que presenciamos: no plano político, ele luta com o "coronel" e pelo "coronel". Aí estão os votos de cabresto, que resultam em grande parte, da nossa organização rural.

Caracterizações como estas estão espalhadas ao longo de todo o livro. As condições objetivas a que estão submetidos os trabalhadores rurais impedem que estes possam ter vontade política própria. Em última análise, os vícios do processo eleitoral decorrem da "fraqueza desamparada e desiludida dos seres quase sub-humanos que arrastam sua existência no trato das suas [a dos coronéis] propriedades" (p. 56).

Há dois mecanismos que se combinam: a pobreza material e cultural e o isolamento ${ }^{5}$. As informações que recebe - as poucas que teria condições de processar - são filtradas, quando não induzidas, pelo patrão ${ }^{6}$. O mundo da política lhe é totalmente estranho. Do ponto de vista práti$\mathrm{co}$, o trabalhador rural só vota porque é levado às urnas pelo seu patrão, que o instrui em quem votar, não sem tomar precauções extras para que de fato vote conforme instruído.

O controle exercido pelo coronel sobre seus eleitores impede que seu voto seja disputado por forças rivais. "A dependência do elemento rural ao fazendeiro, impedindo o contato direto dos partidos com essa parcela notoriamente majoritária do eleitorado" (p. 42) coloca o coronel na posição de um monopolista. Quem quer que queira votos, deve negociá-los com o coronel. Campanhas políticas, portanto, estão fora de questão. Nenhum partido ou corrente política tem como chegar aos eleitores sem a intermediação do proprietário de terras. O capital eleitoral do coronel é líquido e certo. Seus votos podem ser contabilizados de antemão. Eles são despejados nas urnas de acordo com a sua, e apenas a sua, conveniência política.

O proprietário de terra controla os eleitores e, enquanto este controle perdurar, não ocorrerá uma disputa efetiva por votos e a prática do governo representativo do Brasil permanecerá comprometida. O problema de fundo, o problema real, é dado pela constituição do próprio corpo eleitoral, pela sujeição social dos trabalhadores-eleitores. 
Neste registro, o desenvolvimento econômico ou a modernização é o motor de uma possível transformação da realidade política do país. Somente pela alteração da estrutura social e, mais especificamente, das relações sociais vigentes no campo, será possível contar com eleitores em condições de exercer, de fato, o seu direito de voto. A causa das práticas políticas viciadas, para colocar de outra forma, não é institucional ou mesmo política, mas econômica e social. Afirmações neste sentido podem ser recolhidas ao longo de toda obra. Elas estão presentes tanto na página inicial como na final do livro, da clássica - e sempre citada definição inicial de coronelismo às palavras com que o autor fecha a obra: "Todas as medidas de moralização da vida política nacional são indiscutivelmente úteis e merecem o aplauso de quantos anseiam pela elevação do nível político do Brasil. Mas não tenhamos demasiadas ilusões, a pobreza do povo, especialmente da população rural, e, em consequência, seu atraso cívico e intelectual constituirão sério obstáculo às intenções mais nobres"' (p. 258).

De forma mais direta: "parece evidente que a decomposição do 'coronelismo' só será completa, quando se tiver operado uma alteração fundamental da nossa estrutura agrária" (p. 257, ênfase no original). Não há dúvidas que esta seja a proposição forte do livro, o seu tom dominante: a estrutura social herdada do período colonial decretou o fracasso do governo representativo no Brasil e, enquanto esta realidade se mantiver inalterada, todas as iniciativas reformistas estarão fadadas ao fracasso. Invertendo a clássica definição inicial de coronelismo, temos que "o funcionamento de formas desenvolvidas de governo representativo" está associado a "uma estrutura social adequada". O leitor, contudo, pode se indagar: afinal qual seria a estrutura social adequada ao funcionamento do governo representativo?

O leitor não encontra respostas diretas e explícitas a estas questões no livro. Pode-se, obviamente, especular a respeito, derivando das condições negativas observadas as que seriam necessárias para a adequação da prática à forma. Se o problema de fundo é a dependência política do eleitor, causada pela dependência econômica e social, então, pode-se argumentar que a independência do eleitor é a precondição para a vigência de formas desenvolvidas de governo representativo. A estrutura social adequada é aquela em que eleitores são independentes econômica e socialmente. Só nestas condições, eleitores obteriam a necessária independência política, condição para o exercício do direito ao sufrágio e para o funcionamento adequado do governo representativo. 
O argumento é conhecido. $\mathrm{O}$ voto deve ser uma decisão autônoma e, para que assim seja, eleitores devem ser dotados da capacidade necessária para exercê-la. Se o voto é uma decisão tomada após a ponderação das diferentes mensagens que recebe, segue que a disponibilidade dos eleitores, isto é, que estes possam ser alcançados por diferentes mensagens políticas, é um requisito prévio para a ocorrência de eleições competitivas. Além disso, é preciso que eleitores demonstrem ou sejam dotados da capacidade de processar as informações que recebem e de tomar suas próprias decisões. De onde se conclui que, para que o eleitor dependente ganhe autonomia, é necessário que se rompa seu isolamento social e se eleve a sua capacidade cognitiva. Obviamente, esta linha de raciocínio remete a uma questão não menos espinhosa, qual seja, a de identificar as condições sociais necessárias para que um eleitor possa agir de forma independente.

Os fundadores do governo representativo não tinham dúvidas quanto a este ponto. O direito ao sufrágio deveria ser restrito aos proprietários, posto que apenas estes teriam condições de usar seu voto de forma adequada. Por esta razão, uma sociedade formada por pequenos agricultores que trabalhassem suas próprias terras era vista como a mais propícia para a instauração e bom funcionamento do governo representativo. Ao historiar a "invenção do governo popular" na Inglaterra e nos Estados Unidos, Edmund Morgan (1988:157; tradução livre) observa:

A liberdade característica do governo popular depende da independência da população de eleitores e de seus representantes e, por sua vez, que esta independência se assenta sobre a propriedade segura de uma porção de terras suficiente para mantê-los e lhes assegurar a imunidade à coação por parte de empregadores e grande proprietários, uma coação a que os que não possuem terras terão forçosamente que ceder para não perder seus meios de subsistência. A vulnerabilidade dos não proprietários de terra os desqualifica para o exercício do voto. A habilidade para votar independentemente fez dos médios proprietários de terra (yeomanry) os guardiões políticos da liberdade própria aos governos populares

A exaltação das virtudes dos pequenos proprietários de terras, vistos como o único bastião sobre o qual seria possível constituir o governo popular, como nota o mesmo Morgan, conviveu sem maiores problemas com a deferência destes para com os socialmente superiores e com 
a venda pura e simples de seus votos aos grandes proprietários de ter$\mathrm{ra}^{7}$.

A deferência, contudo, não era vista como uma negação dos princípios do governo representativo. Antes o contrário. Para Bernard Manin (1997), a teorização acerca do governo representativo se ancora na suposição que os eleitores independentes deveriam ser capazes de reconhecer os cidadãos mais aptos e capacitados para governar. Mais do que isto, como observa o autor (1997:95; tradução livre), medidas legais asseguravam que tais expectativas se materializassem na prática:

As limitações ao direito de votar nos primórdios do governo representativo são bem conhecidos. (...) O que tem sido menos notado e estudado, contudo, independente destas restrições, existiam também um número de provisões, arranjos e circunstâncias que garantiam os eleitos viriam de grupos sociais mais altos do que o eleitorado. Isto foi obtido de diferentes formas na Inglaterra, França e na América. Pode-se dizer que de forma geral que a superioridade social foi garantida na Inglaterra por uma combinação de medidas legais, normas culturais e fatores práticos e que na França puramente por medidas legais. O caso americano é mais complicado, mas como se verá, mais revelador ${ }^{8}$.

O governo representativo faz demandas contraditórias aos eleitores. $\mathrm{O}$ direito ao voto é reservado aos que reúnem as condições para exercer tal direito com autonomia. Contudo, espera-se que eleitores independentes reconheçam que o governo deve caber aos mais aptos. A independência, portanto, é acompanhada por uma expectativa quanto ao comportamento. Prova ser de fato independente aquele que vota de determinada maneira, que reconhece que os superiores - aristocracia natural, para usar os termos do debate do período - merecem seu voto. Nas palavras de Manin: “O povo deveria escolher livremente dentre os candidatos, como norma, os proprietários e os mais 'respeitados'. Ambas as proposições (e este o ponto essencial) podiam ser verdadeiras ao mesmo tempo. A primeira não poderia ser vista então, e não pode ser agora, como um mero véu ideológico para a segunda" (1997: 125 , ênfase no original) ${ }^{9}$.

Se o voto é um ato de razão, então, espera-se que as escolhas dos eleitores convirjam para um mesmo ponto; que os membros da aristocracia natural sejam os eleitos. Por isto mesmo, não há lugar para campanhas ou disputas pela preferência dos eleitores. Pedir votos é se mostrar in- 
digno de recebê-los. Os superiores são naturalmente reconhecidos como tais.

Voltando a Nunes Leal, a digressão é suficiente para apontar as dificuldades inerentes à sua formulação central. Tomar as qualidades dos eleitores como requisitos ao funcionamento do governo representativo implica adentrar um campo necessariamente minado. De pouco adianta substituir a propriedade pela educação como condição necessária ao exercício adequado ou virtuoso do direito de votar. Não há como estabelecer a priori e de forma objetiva as condições materiais e / ou cognitivas necessárias ao exercício do voto. Não há como fazê-lo sem adentrar o debate político. As condições julgadas suficientes por um observador sempre podem ser consideradas insuficientes ou incompletas por outro, sobretudo, se o resultado das urnas for usado como critério.

No caso da experiência política brasileira, basta mencionar que a ruptura dos laços tradicionais que vinculavam o eleitorado rural aos proprietários de terra não foi visto como condição suficiente para a constituição de um eleitorado independente. Afonso Arinos de Melo Franco (1980:84), comentando as eleições de 1946, afirma:

A liberdade legal não corresponde ainda, todavia, à liberdade psicológica da generalidade dos eleitores, a qual depende de fatores outros, principalmente da elevação do nível econômico e cultural, que só vagarosamente poderemos ir atingindo. (...) Sem dúvida, nas últimas eleições, vários chefes locais foram derrotados, coisa que antes não acontecia. Mas a verdade é que foram derrotados não pelo povo organizado, e sim por outros chefes. (...) O povo do interior ainda confia mais na ação dos chefes políticos próximos do que na promessa dos oradores distantes. Esse patriarcalismo eleitoral do interior tem como correspondente, nas cidades, o caudilhismo eleitoral. O fenômeno, no fundo, é o mesmo e provém de causas equivalentes: baixo nível cultural, indiferença por programas, confiança nos indivíduos e não nas ideias. Nas cidades, o patriarca, o coronel é o caudilho. A massa urna é mais confiante em si, menos submissa, por isto supõe-se mais livre. De fato vota, como a rural, fascinada pelo impulso personalista. O coronel das cidades é Prestes, é Getulio, é Ademar, é Otacílio.

O juízo fala por si ${ }^{10}$. O fato é que a elevação do nível "cultural e material" dos eleitores sempre pode ser julgado insuficiente para garantir que o voto seja verdadeiramente livre, sobretudo quando os eleitores votam em desacordo com as expectativas do que o observador consi- 
dera razoável ${ }^{11}$. O próprio Nunes Leal, como registra José Murilo de Carvalho (1977) comentando artigo de ocasião do autor, foi presa das ciladas deste argumento ao observar que o "coronelismo" teria se metamorfoseado e tomado nova forma sob o regime militar ${ }^{12}$.

Não é fácil, como se vê, identificar qual seria a estrutura social adequada às formas avançadas de governo representativo. Argumentos com este sentido levam, necessariamente, a um beco sem saída. Como procurarei mostrar adiante, tampouco é claro que a base material e social descrita por Nunes Leal leve necessariamente à deturpação dos princípios do governo representativo ou mesmo, sendo mais específico, que determinem que eleições não podem ser competitivas. Por paradoxal que possa parecer, os argumentos negando esta relação podem ser encontrados em Coronelismo, Enxada e Voto. Obviamente, tal proposição pede a preliminar, qual seja, a de definir o padrão a partir do qual o governo representativo será julgado. Como de fato funcionam (ou devem funcionar) eleições em formas avançadas de governo representativo?

Nunes Leal emprega mais de um termo para desqualificar a experiência eleitoral brasileira. Não poucas vezes, temos uma enumeração de mazelas em que termos como insinceridade das urnas, inversão do princípio representativo, violência, fraude e governismo são apresentados como facetas de um mesmo fenômeno. Ao longo do livro, esta caracterização por enumeração tende a ser aplicada indistintamente a todos os períodos e fases da política brasileira, da Independência à Revolução de $1930^{13}$. Nesta reconstituição, contudo, o período que se segue à queda do Estado Novo é distinguido dos demais. As eleições de 1945 são tomadas como um verdadeiro divisor de águas. A diferença entre estes dois grandes períodos é dada pelo caráter competitivo assumido pelas eleições. A base sobre a qual se assenta esta distinção é, como procurarei mostrar, a derrocada do governismo, o fato de as oposições passarem a contar com chances reais de derrotar o governo.

Nunes Leal não apenas constrói o contraste entre as eleições pré- e pós-1945, como também se vê forçado a explicar esta ruptura. Mais interessante: Nunes Leal não invoca a estrutura social para dar conta da nova realidade política que observa. A explicação que oferece tampouco é institucional. Nunes Leal minimiza o impacto do Código Eleitoral de 1932 e de suas alterações posteriores. No geral, para o autor, estas reformas merecem o mesmo tratamento de todas as reformas eleitorais anteriores. A história da legislação eleitoral brasileira seria marcada 
por um reformismo "incansável", no qual todas as fórmulas disponíveis teriam sido tentadas, mas

através de todas essas tentativas (...) o mecanismo representativo continuou a revelar deficiências, por vezes graves (...) Mas mesmo nas épocas em que o processo eleitoral se apresentou menos contaminado de violência ou fraude, sempre impressionou aos espíritos mais lúcidos o artificialismo da representação, que era de modo quase invariavelmente maciçamente governista (p. 241).

A passagem, como sói acontecer ao longo do livro, é fechada com a reafirmação de que os fatores econômicos e sociais são as verdadeiras causa das mazelas observadas, já que a "subsistência de certos vícios exteriores ou formais" contribuía decisivamente para que

se atribuíssem os defeitos do nosso regime representativo a fatores de ordem puramente ou predominantemente política. Por esse mesmo motivo, a atenção dos observadores quase invariavelmente se desviava dos fatores de econômicos e sociais, mais profundos, que eram e ainda são os maiores responsáveis pelo governismo e, portanto, pelo falseamento do intrínseco da nossa representação (p. 241).

A passagem, como se lê ao seu final, contém mais do que reafirmação da tese central do livro, uma vez que traz consigo uma definição clara do problema a ser explicado: a manifestação "do falseamento intrínseco da nossa representação" é o governismo. Mesmo quando as eleições estiveram a salvo da violência e da fraude, a representação política tendeu a ser "invariavelmente maciçamente governista". E é isto que teria deixado de ocorrer a partir de 1945. Por isto mesmo, inaugurou-se ali o primeiro experimento do país com a democracia.

Pode-se argumentar que reduzir o problema do falseamento da representação no Brasil ao governismo não faz jus à contribuição de Nunes Leal. O valor da obra estaria justamente em mostrar o caráter multidimensional do fenômeno. $O$ falseamento ou mistificação da representação no Brasil envolveria, entre outras coisas, a coação sobre o eleitor, a violência contra a oposição, a fraude eleitoral e, por último e provavelmente menos importante, o governismo. A importância da contribuição de Nunes Leal estaria justamente em mostrar como estas facetas estão interconectadas, como seriam a expressão de um mesmo fenômeno ou síndrome, para usar uma analogia médica. 
Não é o meu intuito propor uma nova leitura da obra de Nunes Leal. Não é o caso de rever as interpretações sobre a obra. Não busco comprovar qual a leitura correta da obra ou quais seriam as verdadeiras ideias do autor. Na realidade, como disse, isto já foi feito e não há muito a acrescentar às competentes revisões citadas anteriormente. Como dito na introdução, meu objetivo é tomar Nunes Leal como referência para entender uma questão analítica, a saber, entender as condições em que governos podem ser derrotados em eleições. Por isso mesmo procuro distinguir o "governismo" das demais facetas da "insinceridade das urnas", como fraude e violência. O governismo é a expressão mais completa do "falseamento do governo representativo". Eleitores não têm opções senão sufragar os candidatos apoiados pela situação. O princípio representativo se inverte: em lugar do governo ser o produto da escolha dos cidadãos, dá-se o contrário, o governo escolhe os eleitores ${ }^{14}$.

Na seção seguinte, mostro que Nunes Leal não vincula o governismo à grande propriedade e à dependência social do eleitor. Nada impede que proprietários de terra disputem o poder entre si. $\mathrm{O}$ fato de as eleições não serem competitivas não decorre da estrutura social. O governo sempre vence as eleições, mas o faz sem controlar diretamente os eleitores. O controle é, por assim dizer, descentralizado. Esta é uma das grandes contribuições da obra: apresentar um modelo em que há coordenação e alinhamento políticos dos líderes dos três níveis distintos de governo. O que há por explicar é porque o chefe político local, o "coronel", que comanda "discricionariamente um lote considerável de votos de cabresto" (p. 23), se vê impelido a perfilar-se com o governo.

\section{GOVERNISMO E POLÍTICA LOCAL}

O caráter não competitivo das eleições não decorre da estrutura social do país. A grande propriedade e a sujeição do trabalhador rural ao proprietário não são condições suficientes para explicar a ausência de competição política no plano local. A razão é simples, conforme explica o próprio Nunes Leal: "A primeira observação de quem estuda o coronelismo é, natural e acertadamente, atribuí-lo à hegemonia social do dono de terras. Mas é preciso entender essa hegemonia apenas em relação aos dependentes da sua propriedade, que constituem seu maço de votos de cabresto. Não é possível entender essa hegemonia em relação a todo o município" (p. 53). 
O autor completa seu raciocínio observando:

Se um só coronel fosse dono de um distrito inteiro, a sua hegemonia social, resultante da propriedade da terra, seria incontestável naquela circunscrição, o mesmo ocorrendo em relação a todo o município, quando fosse o caso. Havendo, porém, como é a regra, vários fazendeiros em cada distrito e número bem maior em cada município, seria natural que espontaneamente se agrupassem em mais de uma corrente partidária, atendendo aos diversos fatores que determinam as ligações políticas municipais (p. 55).

Estas passagens são suficientes para afastar uma leitura reducionista ou determinista da relação entre poder econômico e poder político. Ainda que a terminologia seja anacrônica, é necessário notar que o coronel é um empresário político. Para que o trabalhador rural seja transformado em eleitor, é preciso não apenas custear o seu alistamento como também os gastos incorridos no dia da eleição:

Há ainda as despesas eleitorais (...). São pois os fazendeiros e chefes políticos locais quem custeiam as despesas do alistamento e da eleição. Sem dinheiro e sem interesse direto, o roceiro não faria o menor sacrifício nesse sentido. Documentos, transporte, alojamento, refeições, dias de trabalho perdidos, e até roupa, calçado, chapéu para o dia das eleições, tudo é pago pelos mentores políticos empenhados na sua qualificação e comparecimento. (p. 36)

Nem todos os proprietários de terra incorrerão nestes custos, e os que o fizerem não serão bem-sucedidos politicamente se contarem apenas com seus trabalhadores. Portanto, um coronel precisa articular os interesses de um grupo de proprietários de terra e, assim, nada impede que coronéis entrem em conflito, que representem, por qualquer razão que seja, diferentes grupos de proprietários de terra e se vinculem a diferentes grupos políticos estaduais e/ou nacionais ${ }^{15}$.

Assim, no plano local, diferentes facções políticas disputam o poder. Segundo a caracterização de Nunes Leal, eleições locais são "renhidas" e mais "verdadeiras" que as estaduais e nacionais: "As eleições municipais constituem pelejas tão aguerridas em nosso país, justamente porque é pela comprovação de possuir a maioria do eleitorado no município que qualquer facção local mais se credencia às preferências da situação estadual" (p. 49). 
Há, portanto, confronto entre diferentes "coronéis". Mais do que isto, estes tendem a ser violentos. A base política última e os métodos a que recorrem para arregimentar seus eleitores são, muito provavelmente, os mesmos. Não importa. O fato é que facções locais disputam o poder local. Contudo, este é um ponto essencial do argumento, o objetivo último destas disputas é se "credenciar" junto à situação estadual. O que cada facção procura é comprovar que tem a maioria do eleitorado do seu lado. Logo, em cada município há coronéis que se perfilam com o governo e os que se encontram na oposição:

É evidente, como já ficou indicado, que nem todos os chefes de facções municipais, nem todos os "coronéis" são aliados do oficialismo estadual. Podem estar na oposição, como se vê em quase todos os municípios. Mas a situação de oposicionista, no âmbito municipal, é tão desconfortável que a regra é ficar na oposição somente quem não pode ficar com o governo. Segundo já tem sido observado, as correntes políticas municipais se digladiam com ódio mortal, mas comumente o que cada uma delas pretende é obter as preferências do governo do Estado; não se batem para derrotar o governo no território do município, a fim de fortalecer a posição de um partido estadual ou nacional não-governista: batem-se para disputar entre si o privilégio de apoiar o governo e nele se apoiar (pp. 48-49).

Eleições locais são "aguerridas", "renhidas", violentas, contudo, não são verdadeiramente competitivas. A facção vitoriosa na disputa local adere ao governo estadual e, ao fazê-lo, passa a contar com os recursos do Estado para assegurar a vitória nas disputas futuras. O controle sobre o Estado, sobretudo o uso da violência, legal e extralegal, garante a perpetuação no poder. Estabelece-se, desta forma, o sistema de trocas ou reciprocidade que alimenta o compromisso entre o coronel e o governo estadual: "da parte dos chefes locais, incondicional apoio aos candidatos do oficialismo nas eleições estaduais e federais; da parte da situação estadual, carta branca ao chefe local governista (de preferência o líder da facção local majoritária) em todos os assuntos relativos ao município, inclusive na nomeação dos funcionários estaduais no lugar" (p. 50).

Mas por que o chefe político estadual adere ao governo estadual? Por que o coronel não poderia permanecer na oposição ou ainda afirmar a sua independência em relação à política estadual? Estas não são opções politicamente viáveis em função da falta de autonomia dos muni- 
cípios, do "amesquinhamento das instituições municipais" (p. 50). Conforme argumenta Nunes Leal:

Se garantida juridicamente contra as intromissões do poder estadual e assentada em sólida base financeira, a autonomia do município seria naturalmente exercida, no governo representativo, pela maioria do eleitorado, através de seus mandatários nomeados nas urnas. Mas com a autonomia legal cerceada de várias formas, o exercício de uma autonomia extralegal fica dependendo inteiramente das concessões do governo estadual. Já não será um direito do eleitorado; será uma dádiva do poder (p. 50, ênfase minha).

Opera-se assim a completa "inversão do sistema representativo", uma situação em que o eleitorado é predisposto "em favor dos candidatos governistas", dado que a "força aglutinadora do governo" atua na razão direta do "amesquinhamento do município". De forma mais concreta:

Dentro desse quadro, o êxito de uma parcialidade nas eleições municipais será uma Vitória de Pirro, a não ser que ela seja, ou venha a tornar-se aliada da situação estadual. Por virtude dessa completa inversão de papéis, é evidente que, em regra, os candidatos aos cargos municipais sufragados pela maioria do eleitorado não resultam de uma seleção espontânea, mas de uma escolha mais ou menos forçada. Se os candidatos ao governo municipal, que forem apoiados pelo governo estadual, são os que têm maiores oportunidades de fazer uma administração proveitosa, esse fato já predispõe decisivamente grande número de eleitores em favor do partido governista. Em tais circunstâncias, mesmo as eleições municipais mais livres e regulares funcionarão, frequentemente, como simples chancela de prévias nomeações governamentais. Autêntica mistificação do governo representativo (p. 52).

Eis porque o sistema representativo é invertido: a maioria não escolhe livre e espontaneamente os governantes. E isto ocorreria mesmo em uma situação limite em que as eleições fossem "livres e regulares". A escolha é induzida, mais ou menos forçada, pelo alinhamento prévio com as forças dominantes no plano estadual e as vantagens decorrentes. Contassem os municípios com autonomia legal e financeira, e a maioria poderia fazer suas escolhas, não teria que se inclinar necessariamente em direção ao oficialismo. Enquanto perdurar esta dependência, eleições não serão "limpas e regulares" porque o apoio do governo 
estadual confere ao governante local a "carta-branca" para usar a coação estatal com fins político-eleitorais:

E aqui o apoio do oficialismo estadual ao chefe do município, seja por ação, seja por omissão, tem a máxima importância. Nesse capítulo, assumem relevo especial a figura do delegado e do subdelegado de polícia. A nomeação dessas autoridades é de sumo interesse para a situação dominante no município, e constitui uma das mais valiosas prestações do Estado no acordo político com os chefes locais. Embaraçar ou atrapalhar negócios ou iniciativas da oposição, fechar os olhos à perseguição dos inimigos políticos, negar favores e regatear direitos ao adversário - são modalidades diversas da contribuição do governo estadual à consolidação do prestígio de seus correligionários no município. Mas nada disto via de regra se compara a esse trunfo decisivo: pôr a polícia do estado sob as ordens do chefe situacionista local (p. 47).

Eleições são, nestes termos, verdadeiras mistificações. O sistema está invertido. Quem conta com o apoio oficial usa o poder do estado para perseguir e oprimir os inimigos e, desta forma, controlar as eleições em que, não surpreendentemente, sempre vencem. Segue daí que eleições são inteiramente destituídas de sentido? Por que afinal de contas se recorre a eleições se o resultado destas está definido de antemão? ${ }^{16}$ Passagens citadas anteriormente indicam a resposta: facções locais qualificam-se como representantes locais do governo estadual quando comprovam controlar a maioria do eleitorado. Por isto, o escolhido como chefe local deve preferencialmente ser o líder da facção local majoritária.

Em certas circunstâncias, as ameaças e violências desempenham papel primordial, porque semelhantes processos podem, por vezes, garantir o governo municipal à corrente local menos prestigiada. Mas a regra não é esta: a regra é o recurso simultâneo ao favor e ao porrete. Compreende-se isso perfeitamente, quando se considera que à situação dominante no Estado o que interessa é consolidar-se com o mínimo de violência. A não ser a um desequilibrado, ninguém pratica o mal pelo mal: em política, principalmente, recorre-se à violência, quando os outros processos são mais morosos ou ineficazes para os fins visados. Por isso mesmo, frequentemente, o oficialismo estadual apoia a corrente que já conseguiu a posição preponderante no município (pp. 48-49).

A inversão não é completa. Eleições funcionam como um aferidor de forças, revelando a capacidade de um determinado grupo em exercer o 
poder recorrendo ao mínimo necessário da violência. Mas o exercício do poder traz consigo retornos no plano eleitoral. Por isto mesmo, o vencedor da eleição de hoje dificilmente perderá as eleições subsequentes. Enquanto garantir a maioria dos votos locais, o chefe local se credencia a receber as benesses do oficialismo, a carta branca para usar os recursos do Estado para se perpetuar no poder.

O compromisso coronelista representa, nestes termos, um equilíbrio, no sentido técnico do termo. Nenhum ator tem interesse em alterar seu curso de ação. Nenhuma das partes ganha se o fizer unilateralmente. Nenhum coronel se beneficia se opondo ao governo estadual, e este nada ganha se deixar de apoiar o poderoso local. Mais do que isto, o sistema se mostra à prova de choques. À improvável derrota de um chefe local situacionista segue-se a adesão do vitorioso ao oficialismo. E o novo adepto do governo passa, imediatamente, a contar com os recursos do Estado para perseguir o derrotado, assegurando o controle sobre a maioria do eleitorado nas próximas eleições.

Nunes Leal observa que, se a sorte política dos municípios “dependesse exclusivamente do eleitorado, isto é, dos cabos eleitorais urbanos e dos diversos fazendeiros dos distritos", ou seja, se estas estivessem a salvo da "força aglutinadora do governo, aumentada na razão direta do amesquinhamento do município", então, "cada eleição, com toda a probabilidade, seria uma batalha incerta, ou pelo menos muito custosa" (p. 55). E a razão de ser a última da troca de apoios que se estrutura entre os diferentes níveis de governo é justamente a de eliminar esta incerteza, a incerteza que decorreria de eleições decididas inteiramente pela distribuição de forças locais.

O argumento reconstituído nesta seção prescinde inteiramente da referência à grande propriedade e do controle social exercido sobre os eleitores. O governismo assenta-se sobre outras bases. Na realidade, para que a ausência de competição eleitoral seja derivada da estrutura agrária, a premissa crucial não se refere às preferências dos eleitores, mas a dos proprietários de terra, a presumida unidade entre eles. Nunes Leal não assume que esta unidade esteja dada. Antes o contrário. Eleitores são mobilizados por diferentes correntes políticas, levando a eleições locais renhidas, violentas.

O que efetivamente explica o governismo é o amesquinhamento dos municípios, sua falta de autonomia legal e financeira. Nunes Leal, portanto, critica o antimunicipalismo característico, a seu ver, tanto do pe- 
ríodo imperial quanto da Primeira República, notando o seu aspecto contraditório, quando não paradoxal: "assim como se vê como nossos juristas-idealistas, que pretendiam limitar o poder dos municípios para impedir as oligarquias locais, acabaram dando aos governadores os meios de que se serviriam eles para montar em seu proveito, essas mesmas oligarquias locais" (p. 102).

O raciocínio, portanto, inverte o tradicional argumento em favor da centralização política. As limitações à autonomia local seriam necessárias em função da incapacidade das elites locais praticarem de forma salutar o autogoverno. Elites locais, neste argumento, precisariam ser tuteladas. Esta seria a forma de evitar a degeneração do autogoverno, sua transformação em governo oligárquico. Contudo, o controle desde cima não neutraliza a tendência à oligarquia. Antes o contrário. As oligarquias são as grandes beneficiárias deste arranjo. O principal efeito da centralização é a eliminação da incerteza que eleições definidas inteiramente no plano local poderiam acarretar. A oligarquia local se acomoda sob o controle das oligarquias estaduais.

O argumento comporta uma aposta nos efeitos benéficos da descentralização. Obviamente, a crítica à centralização não prova seu contrário, isto é, que a autonomia dos municípios seria condição suficiente para tornar eleições locais verdadeiramente competitivas. A consequência da descentralização pode ser um tipo diferente de governismo, um governismo assentado em bases locais. Se o governante local controlar os recursos cruciais para influenciar o resultado das urnas, por que estes não seriam empregados para derrotar a oposição? Trata-se, como dito antes, de uma aposta. Por certo, uma aposta consequente com os princípios liberais e representativos. O realismo dos centralizadores encerra uma contradição, uma vez que reforça e consolida o quadro sobre o qual o diagnóstico se justifica, negando na prática o que afirma em teoria ser a condição para o sucesso do governo representativo: a experiência com o autogoverno.

\section{FRAUDE, VIOLÊNCIA ELEITORAL E DEMOCRATIZAÇÃO}

O mecanismo representativo se inverte quando o governo controla a manifestação das urnas. Eleitores não têm escolha. Sua vontade é dada de antemão pelo sistema de trocas em que estão envolvidos. E, na realidade, os coronéis tampouco têm espaço para fazer escolhas. 
Nesta inversão, sem dúvida alguma, fraudes desempenham um papel importante. Contudo, uma coisa é dizer que as práticas correntes fraudam os princípios do sistema representativo, outra é dizer que estas "verdadeiras mistificações eleitorais" eram objetos de fraude. Há que se distinguir, portanto, o juízo de que os princípios do sistema representativo são fraudados da ocorrência das fraudes. Ainda que a distinção possa parecer bizantina, não é assim tão fácil distinguir uma coisa da outra sem incorrer em anacronismos. Por exemplo, aos olhos contemporâneos, a prática do voto público ou a descoberto é suficiente para levantar suspeitas sob a lisura do pleito em questão. Contudo, pelas razões já identificadas anteriormente, o voto público e aberto foi tido por muito tempo como desejável e, mesmo, como um anteparo necessário à ação das influências corruptoras e nefastas sobre a vontade independente do eleitor. Pretender votar de forma sigilosa só pode ser justificado por aqueles que cederam a pressões corruptas e indignas. $\mathrm{O}$ eleitor provaria sua independência ao declarar seu voto publicamente.

Portanto, ao se referir à fraude eleitoral, é preciso ter claro o que estava autorizado na lei eleitoral vigente. Em um sentido estrito, a fraude pode ser definida como a alteração dos resultados expressos nas urnas de forma ilega ${ }^{17}$. Se definida desta maneira, deve se concluir que a fraude é um componente menor no funcionamento do sistema representativo descrito por Nunes Leal ${ }^{18}$. E a razão para tanto é a própria lógica que alimenta e sustenta o governismo. Se todos os atores envolvidos no processo se comportarem como o esperado, e como vimos não há razão para que não o façam, por que seria necessário recorrer à fraude?

Quando se debate a fraude eleitoral na Primeira República, o papel da Comissão de Verificação de Poderes sempre vem à baila. Contudo, a despeito de toda a importância que normalmente lhe é atribuída, Nunes Leal a vê como um elemento acessório e menor na cadeia de acordos e compromissos que sustentam o governismo ${ }^{19}$. Comentando a montagem da Política dos Governadores e o papel que a "engenhosa máquina de depuração e degola dos candidatos oposicionistas" desempenhava em seu interior, Nunes Leal nota que o "reconhecimento funcionava, portanto, como instrumento complementar da dominação pelas situações estaduais" (p. 247). Em geral, presidente e governadores eram capazes de acomodar seus interesses, sendo desnecessárias as alterações explícitas dos resultados eleitorais. Somente "nas vésperas da sucessão presidencial é que este lago tranquilo costumava, por ve- 
zes, encrespar-se, quando alguns governadores divergiam da escolha do candidato oficial" (p. 246). Em outras palavras, as degolas eram reservadas para momentos críticos, nos poucos momentos que o equilíbrio se rompia, quando o lago tranquilo se encrespava ${ }^{20}$.

Não segue deste comentário que eleições fossem limpas ou verdadeiras, como quer que estes termos sejam definidos. Pacíficas, como já foi observado, com certeza não eram. Nunes Leal corrobora o juízo corrente e disseminado acerca dos vícios que caracterizaram as práticas eleitorais no Império e na Primeira República. O processo como um todo seria maculado, do alistamento à apuração, passando obviamente pelo próprio ato de votar. Ainda que assim fosse, o argumento invocado para minimizar a importância da Comissão de Verificação dos Poderes pode ser invocado para qualificar o que de fato ocorria nos demais momentos do processo eleitoral.

Além do mais, como notado anteriormente, é necessário observar que a crítica generalizada às práticas eleitorais passadas acaba por perder a necessária perspectiva histórica. O que se entende por eleições "verazes e limpas" se modificou no tempo. Como já salientado, Nunes Leal minimiza os efeitos do Código Eleitoral de 1932, assim como de suas modificações posteriores sobre o aperfeiçoamento do processo eleitoral. Não que repute as inovações feitas como nulas. As eleições ocorridas após a instauração da Justiça Eleitoral são tidas como as mais limpas e verdadeiras de quantas tivemos. Contudo, por si só, retirar do governo o controle direto sobre as diferentes fases do processo eleitoral não é suficiente para afastar inteiramente a sua influência sobre os resultados eleitorais. O essencial não teria mudado. Tome-se, a título de exemplo, o seguinte comentário:

Com efeito, de todas as eleições havidas até então foram as de maio de 1933 as mais regulares quanto ao mecanismo de alistamento, da votação e apuração do reconhecimento. Na cúpula do sistema estava o TSE, que decidia as dúvidas e impugnações em estilo judiciário, isto é, pelo alegado e provado, e segundo consta, sem interferência da política partidária. Apesar disso, os deputados que representavam a situação política nos respectivos estados foram em muito maior número que os oposicionistas. A verdade formal das eleições não impediu, portanto, o predomínio do governismo, cujos fatores já não podiam ser considerados exclusiva ou preponderantemente políticos (pp. 241, 242). 
O governismo poderia, portanto, conviver com a verdade formal das eleições. Para que vença eleições, o governo não precisa recorrer ao controle direto do processo eleitoral. Em passagem anterior, Nunes Leal havia observado que

O código de 1932, aperfeiçoado pela reforma de 35, apesar dos louvores que mereceu, não punha fim à costumeira coação dos partidos oficiais. Não nos referimos à coação direta e material no dia do pleito ou no ato de votar. Nem era esta a mais frequente modalidade de compressão do voto na vigência das leis anteriores. Aludimos à coação difusa, mas efetiva, que em muitos lugares precede as eleições no interior do país; ao ambiente de insegurança adrede criado para os eleitores da oposição, que nos menores municípios toda gente conhece; à violência preparatória, atual ou iminente manifestada com pertinácia em pequenas ou grandes façanhas, dias, semanas e até meses a fio. Para esse tipo de coação, não havia remédio segundo a interpretação restritiva que lhe deu o Tribunal Superior Eleitoral (p. 234).

O governismo, portanto, depende menos da coação direta e localizada, forma de "compressão do voto" menos frequente do que normalmente se pensa, do que da difusa e continuada. A Justiça Eleitoral pode minorar a primeira, mas se julgou incapaz de remediar a segunda. A distinção é importante. Há duas formas de coação, a direta e a difusa. Neste ponto, como em outras oportunidades, Nunes Leal se vale de Domingos Velasco para especificar a forma pela qual a coação difusa toma corpo: o uso da violência para afugentar das urnas o eleitorado oposicionista $^{21}$. O ponto merece ênfase por especificar a maneira pela qual a "carta branca" recebida pelos poderosos locais se transformava em uso da violência, no mais das vezes amparadas pelas autoridades, com vistas a assegurar a vitória nas urnas. Negar a oposição o exercício do direito ao voto, eis, de forma resumida, como a compressão eleitoral funcionava. Os comentários de Raquel de Queiroz, citados por Nunes Leal (p. 242, nota 75) após servir como mesária na eleição de 1945, são significativos: "Não sei bem se o sentimento será de saudade; mas a verdade é que a eleição mudou muito. Recordo da eleição do tempo de dantes - tiro, comedorias, botina de graça para os eleitores, cachaça a rodo, era um carnaval. Votava vivo e votava morto, votava doido do hospício, só não votavam nossos inimigos políticos".

As distinções feitas, assim como a especificação do objetivo primeiro do recurso a coação, impedir que os inimigos da situação votassem, contribuem para um melhor entendimento do processo eleitoral no 
Império e na Primeira República. Seja como for, a despeito de reconhecer os avanços registrados com o advento da Justiça Eleitoral, Nunes Leal, em diversas passagens, enfatiza que esta não tem como impedir a coação sobre eleitores. A complexidade da questão enfrentada fica evidente no julgamento de ação relativa às eleições estaduais de Sergipe, em 1947, quando se pleiteou a impugnação da eleição por "haverem associações religiosas e sacerdotes recomendado e pregado que os eleitores católicos não poderiam sufragar os candidatos da UDN, sob penas de pecado mortal" (p. 239). Nunes Leal comenta que ao se eximir de analisar o pedido, o TSE manteve-se fiel a um conceito restrito de coação. Ao comentar os resultados das eleições de 1947, Nunes Leal observa que alguns tribunais estaduais foram objeto de crítica por não terem observado a necessária ou esperada imparcialidade política. O comentário é rematado com uma transcrição de artigo de 1933 de Sobral Pinto, "mas não nos iludamos com essas garantias. O governo, que intervinha, ostensiva e desabridamente, no reconhecimento dos poderes, quando este era de alçada das Câmaras Legislativas, bem pode continuar a intervir, com a mesma desfaçatez, no reconhecimento feito pelos Tribunais Eleitorais" (p. 248, nota 88).

A despeito destas ressalvas e, sobretudo, em que pese o fato das características essenciais do eleitorado não terem se alterado, Nunes Leal nota, já no capítulo inicial da obra, que "as eleições de 1945 e 1947 apresentaram certas peculiaridades que lançaram perturbação na tradicional alternativa eleitoral no Brasil: governo e oposição" (p. 37). Mais especificamente, o autor nota que "circunstâncias excepcionais em nossa história política" (p. 236) distinguem as eleições de 1945 e 1947 de todas as demais já ocorridas no Brasil. Quanto às de 1945, seu caráter excepcional decorreu da neutralidade do governo José Linhares, já que "o Chefe de Estado e os interventores, via de regra, recomendaram aos seus subordinados isenção de ânimo na direção da eleição federal" (p. 237). Do ponto de vista prático, Linhares não apenas afastou os interventores, trocando-os por membros do Poder Judiciário, como determinou também que os prefeitos vinculados a partidos políticos fossem igualmente substituídos por membros do judiciário. O excepcional da situação, portanto, é o fato de os governantes não terem procurado influir no resultado eleitoral.

Realizado o pleito e proclamado os vencedores, não era de esperar que os novos governantes mantivessem a mesma "isenção de espíritos". Juízes cederam seus lugares a políticos. O Partido Social Democrático 
(PSD), tendo eleito o presidente e contando com folgada maioria em ambas as Casas, estava em condições de pôr em prática a velha "compressão eleitoral". Não se pode esquecer que Dutra inicia seu governo sob a égide da Carta de 1937, podendo, portanto, nomear os governadores e, estes, os prefeitos.

As eleições para os governos estaduais de 1947 se deram, contudo, sob a vigência do acordo interpartidário PSD-UDN e, nas palavras de $\mathrm{Nu}$ nes Leal, no interior desse

clima de entendimento, pouco interessaria ao Chefe de Governo, com raras exceções, que as eleições estaduais favorecessem o partido governista ou algum dos maiores partidos da minoria. Inspirado ou não apenas por motivos políticos, o certo é que o Presidente da República revelou em regra, louvável imparcialidade no pleito de 19 de Janeiro. Isso explica, em grande parte, por que o situacionismo, em alguns estados, foi derrotado nas eleições para governadores (p. 239).

O acordo PSD-UDN e os "motivos políticos do presidente" Dutra, na realidade, dificultam o próprio entendimento da distinção situaçãooposição em vários estados. Não é tão claro que o presidente tenha se mantido neutro em relação a todas as disputas. Na realidade, por vezes, o presidente não apoia os candidatos mais diretamente identificados com o seu partido e, mesmo, com seu governo. O fato é que este período político é pouco estudado. Não é descabido pensar que Nunes Leal reputa de imparcialidade presidencial uma tentativa mal sucedida de exercer a compressão eleitoral desde a presidência. $O$ fato é que o acordo interpartidário patrocinado por Dutra divide ambos os partidos. Seja como for, para os fins deste artigo, a novidade ressaltada por Nunes Leal se sustenta: a derrota do situacionismo; a ruptura do governismo.

Obviamente, Nunes Leal não estava em condição de fazer juízos definitivos sobre o regime que apenas dava seus primeiros passos. Não é demais lembrar que a obra tem por base texto redigido em 1947. Os seus comentários têm, portanto, caráter especulativo. A ingerência e controle do governo sobre o processo eleitoral (e seus resultados) não estava fadada a desaparecer. Os governantes eleitos estavam em condições de pôr em marcha sistemas análogos aos que imperavam na Primeira República: 
quando o governo José Linhares procurou resguardar a pureza das eleições federais, uma importante medida a que recorreu foi a substituição de prefeitos. E depois do pleito estadual, de 19 de janeiro de 1947, conforme foi amplamente noticiado nos jornais, o problema do provimento das prefeituras ocasionou acerbas disputas políticas, não só no cenário estadual, senão também no federal. Para citar dois únicos exemplos, lembramos os casos de São Paulo e da Bahia. A demissão em massa de prefeitos, decretada pelo governador Ademar de Barros, pouco depois de empossado e sua recusa em compor-se com o PSD paulista para resolver esse magno problema ocasionaram uma tempestade política que veio refletir na esfera nacional. Na Bahia, a nomeação de prefeitos udenistas, nos municípios em que seu partido foi majoritário na eleição de 2 de dezembro de 1945, constituiu, como é notório, o primeiro passo de aproximação entre a UDN e o governo nacional. Os ecos tumultuosos dessa reviravolta estão registrados nos anais da Câmara, onde deputados baianos do partido governista não hesitaram em qualificar de traição a essa conduta. Nenhum outro episódio seria preciso invocar para prova de que a função essencialmente política do prefeito ainda é de fato da mais palpitante atualidade em nosso país (p. 130).

As relações entre os diferentes níveis de governo e como estas iriam se acomodar no interior do regime recém-fundado aguardava melhor definição. As observações de Nunes Leal indicam que a ruptura com a história eleitoral pregressa, se a novidade seria episódica ou se tornaria rotineira, dependia desta definição. A excepcionalidade do período comportava estas duas possibilidades.

A observação é tanto mais relevante quando se atenta para outros períodos históricos igualmente excepcionais da história eleitoral brasileira. Como observam José Murilo de Carvalho (2007:181) e Roderick Barman (1994:211), a primeira intervenção deliberada e consequente do governo no processo eleitoral se deu em 1840, na famigerada "eleição do cacete". Inaugurou-se uma prática seguida por todos os demais Gabinetes. Ou seja, o "governismo" ou a força aglutinadora do governo não teria operado em eleições anteriores, incluindo não apenas as eleições para a Constituinte como ainda as pouco estudadas eleições diretas para regente ${ }^{22}$. Na realidade, em algumas passagens, Nunes Leal observa que a "compressão governamental" nem sempre foi constante. Como observa José Murilo de Carvalho (1988:139), eleições imediatamente posteriores às principais reformas eleitorais do Império (Lei dos Círculos e a Lei Saraiva) caracterizaram-se pela isenção do go- 
verno, manifesta na derrota de candidatos governistas. Nestes termos, as eleições de 1945 e 1947 não são propriamente únicas e excepcionais. A diferença com os episódios anteriores está no fato da exceção ter se tornado a regra, isto é, que as eleições subsequentes se mantiveram competitivas.

\section{CONCLUSÃO}

O Brasil conviveu com eleições entre 1822 e 1930. Voltou a ter eleições regulares em 1945. Contudo, as eleições pós-queda do Estado Novo assumiram caráter radicalmente diverso das verificadas anteriormente. O período que se inaugura com a eleição de 1945 registra a primeira experiência do país com a democracia. A questão que se coloca é, pois, evidente. Por que eleições não eram competitivas e passaram a sê-lo?

Não faltam explicações para a primeira parte da pergunta. As condições objetivas para a prática de eleições "limpas e verazes" não estavam dadas. Enquanto estas condições perdurarem, não se poderá observar senão um arremedo de governo representativo no Brasil. Explicações deste tipo abundam na literatura nacional. Os termos em que são postos e mesmo algumas das variáveis explicativas chaves podem mudar. Mas são variações de um mesmo tema. Em última análise, todas remetem ao mesmo ponto, à formação histórica peculiar do país, à sua estrutura social inadequada e em descompasso com as exigências do governo representativo. Haveria uma dissintonia entre o real e o formal, entre o país real e o país legal.

A segunda parte da pergunta raramente é objeto de tratamento. O que teria mudado em 1945? O fato de o Estado Novo ter suspendido o processo eleitoral por um período relativamente longo contribuiu para colocar a questão na penumbra ${ }^{23}$. Mas o fato é que o contraste entre os dois grandes períodos raramente é feito. Poucos autores enfrentam a questão. Note-se: explicar a queda de Vargas e a derrocada do regime autoritário não é o mesmo que explicar a emergência da democracia. Por que o regime nascente teria que ser democrático? Se nos basearmos na experiência histórica do Brasil até então, na ausência de qualquer evolução efetiva de suas instituições representativas, para não falar das práticas, não seria de esperar que um novo regime autoritário emergisse?

No mais das vezes, a pergunta sequer se coloca, porque referida a uma teoria implícita sobre os efeitos benéficos da modernização econômica 
e social. Somente por meio das transformações da estrutura social, como quer que esta seja caracterizada, será possível reconciliar o formal com o real. As formas desenvolvidas de governo representativo que insistimos em adotar se adequarão a sua base social quando o atraso for superado.

Coronelismo, Enxada e Voto pode ser lido dentro desta chave. Sem a intenção de demonstrá-lo, creio que esta tem sido a forma usual de se ler esta obra. Em inúmeras passagens, como procurei demonstrar, o próprio autor enfatiza e sugere esta leitura. A estrutura social está na raiz do problema. Enquanto eleitores forem controlados pelos proprietários de terra, os princípios do governo representativo serão fraudados.

Contudo, Nunes Leal tece comentários sobre a realidade política que vê nascer. Mais do que notar o contraste, o autor se vê forçado a explicá-lo. Na realidade, o ponto de partida para esta construção é dado pelo caráter conjuntural dos próprios comentários. Nunes Leal escreve logo após a derrubada de Vargas e não tem como ter certeza sobre o destino do novo regime. A possibilidade de que tomasse uma feição não democrática, que os velhos vícios viessem a prevalecer não poderia ser descartada de antemão, sobretudo, se este descarte se baseasse em referência à estrutura social. O Estado Novo, a despeito de seu discurso antioligárquico não havia transformado radicalmente a estrutura agrária do país. Não se deve deixar de notar que os dados citados por Nunes Leal para caracterizar a concentração da propriedade fundiária são de 1940. Assim, se formos fiéis a esta leitura da obra, deveríamos concluir que a excepcionalidade do período 1945-1947 seria passageira. Como em outras oportunidades, a lógica da compressão governamental seria restaurada e voltaríamos a observar eleições não competitivas.

A estratégia inicial traçada por Vargas e seus colaboradores mais próximos, o Plano B, tão bem apresentado por Angela de Castro Gomes (2005), supõe que, para os próceres do Estado Novo, o retorno puro e simples a eleições representaria a restauração das práticas da Primeira República, ou seja, que as velhas oligarquias rurais ainda reuniam as condições necessárias para controlar o grosso do eleitorado. O Plano B, como mostra Castro Gomes (2005) visava justamente substituir os coronéis pelos sindicatos. $\mathrm{O}$ governo controlaria o processo eleitoral ao estabelecer seu controle sobre o alistamento, definindo o corpo eleitoral. 
Dado o momento em que escreve, Nunes Leal não pode desconsiderar a possibilidade de que o regime nascente viesse a conviver com eleições não competitivas. Não estava implícito que o regime seria democrático, ainda que as primeiras eleições se mostrassem excepcionais, que apresentassem traços que as diferenciavam de todas quantas haviam se verificado no passado. Uma das grandezas da obra está, justamente, em identificar esta novidade. Mais do que isto, está em precisar o que distingue os dois períodos, a saber, o fim do governismo; a possibilidade de que o governo fosse derrotado nas urnas.

Tomando o "governismo" como o fio condutor da obra, Coronelismo, Enxada e Voto ganha nova coloração. A estrutura agrária deixa de ser um fator determinante. $\mathrm{O}$ argumento se desloca da estrutura agrária para o "amesquinhamento do município". É o fato de o poder local não ser dotado de autonomia legal e financeira que explica o caráter não competitivo assumido pelas eleições. Facções locais lutam para se credenciar como os representantes da situação, do oficialismo. A adesão à oligarquia dominante no Estado garante a perpetuação da elite local no poder. A natureza da troca de apoios é política e independe da base social sobre a qual o poder local se assenta. O crucial é que a elite local conte com a "carta branca" para coagir a oposição e consolidar seu poder.

Eleições, contudo, não são pura farsa ou completa mistificação. Eleições funcionam como aferidor da força dos diferentes grupos, um indicador da força relativa das facções locais para impor a ordem. O controle do eleitorado é uma função do poder social do chefe local. Vencer as eleições é dar provas deste poder. O governo estadual, nada mais tem a fazer que referendar o poder de fato da facção vitoriosa nas urnas, confiando-lhe o exercício do poder estatal no plano local. Ao fazê-lo, o acordo que se estabelece entre chefes locais e estaduais garante a ambas as partes vitórias nas eleições futuras. O acordo é estável e a prova de choques passageiros e localizados. Além disto, por meio desta troca de apoios, ambas as partes minimizam o emprego da força.

Visto deste ângulo, o regime eleitoral vigente na Primeira República ganha significado. Não se tratava de uma farsa, da adesão a um formalismo totalmente destituído de sentido. Eleições, de uma forma ou de outra, regularam o conflito político. Afinal, membros do Poder Legislativo e, sobretudo, presidentes foram eleitos por mais de trinta anos de acordo com o calendário eleitoral. 
Coronelismo, Enxada e Voto tem um caráter único no interior da reflexão política nacional. Salvo melhor juízo, Nunes Leal é o único autor a problematizar a ruptura verificada após a queda do Estado Novo, a propor uma periodização de nossa história político-eleitoral que distingue estes dois momentos. Não há, por certo, uma teoria da democratização em Nunes Leal. Tampouco há uma afirmação peremptória de que o novo regime viria a ser democrático. As duas eleições que observa são rotuladas de verdadeiramente excepcionais. Nada garantia que estas condições seriam mantidas no futuro, sobretudo, se levarmos em conta o caráter circunstancial das causas invocadas. Mas este é o ponto alto da contribuição do autor. A possibilidade de um retorno puro e simples à política dos governadores, ou uma variante daquela fórmula, não é desconsiderada. O autor não descarta a possibilidade de uma restauração do "governismo". As condições políticas para tanto eram amplamente favoráveis. O PSD conta com ampla maioria na constituinte e Dutra inicia seu mandato sob a égide da Constituição de 1937, o que lhe conferia o direito de nomear os governadores estaduais e, por meio destes, os prefeitos, podendo assim influir diretamente nas eleições estaduais e municipais. As condições políticas estavam dadas para que a força aglutinadora do governo e a compressão eleitoral voltassem a operar. Por que isto não ocorreu?

A explicação oferecida é política e não social. Em tempos de neoinstitucionalismo, cabe frisar a ressalva: a explicação é política, mas não institucional. Nunes Leal minimiza o impacto do Código Eleitoral de 1932 e de suas transformações subsequentes. No seu argumento, subentende-se que o governo ainda pode manter a "compressão eleitoral" em operação mesmo quando alijado do controle direto do processo eleitoral. Não há garantias sequer de que o próprio Tribunal Eleitoral não venha a ser controlado pelos governos estaduais.

A democratização de 1945 aguarda novos estudos. Paradoxalmente, a literatura sobre o período tende a frisar a continuidade entre o Estado Novo e a democracia nascente ${ }^{24}$. A ruptura é negligenciada. Nunes Leal não a minimizou. Antes o contrário. Mais do que isto, seus comentários captam o que há por explicar. Governos por vezes são neutralizados. Resta saber se as condições excepcionais que levaram a tanto podem ser generalizadas.

(Recebido para publicação em fevereiro de 2012)

(Versão definitiva em março de 2012) 


\section{NOTAS}

1. “Face à inexistência, em 1945, de qualquer movimento contestatório de amplas bases sociais, ou inspirado em metas ideológicas capazes de levar a uma confrontação mais drástica, a proposição de que partimos - a existência de continuidade em importantes aspectos político-institucionais - nada tem de surpreendente" (Campello de Souza, 1990:105). Em favor da autora deve se ressaltar que seu principal objetivo é explicar a quebra da democracia em 1964. Além disto, o livro permanece fundamental para o entendimento da conjuntura que cercou a queda do Estado Novo.

2. Uma breve referência se encontra em Benevides (1981:72).

3. Por exemplo, sequer discuto o conceito de coronelismo ao longo deste texto. Para uma interpretação do coronelismo e do teor geral da obra, consultar Carvalho (1977) e a literatura revisada pelo autor. O leitor interessado não pode deixar de consultar também a excelente discussão feita por Cintra (1974). Na realidade, creio que nada do que apresento deixa de ser tratado nos textos citados. A novidade, se ela existir, é de ênfase. Somente ao revisar o texto para publicação tomei conhecimento da existência do Instituto Victor Nunes Leal e seu valioso acervo. Consultar http: / / www.ivnl.com.br.

4. Todas as citações de Coronelismo, Enxada e Voto foram retiradas da segunda edição de 1975. A edição original é de 1949. Doravante, referências à obra conterão apenas o número da página.

5. Andrade (2004:205) enfatiza estas duas variáveis explicativas, assim como o amesquinhamento do município, a ser tratado adiante.

6. A importância do isolamento do trabalhador rural no argumento do autor fica clara na seguinte passagem: "Esse panorama já se apresenta, aliás, com alguns indícios de modificação, segundo pode ser observado nas eleições verificadas em 1945 e 1947. No seio do próprio eleitorado rural verificaram-se traições dos empregados aos fazendeiros. O fato merece um estudo atento a que ainda não foi feito. Observadores locais costumam atribuí-lo à propaganda radiofônica" (p. 36).

7. A discussão de Morgan se refere ao século XVIII. Hanham (1978) mostra que as práticas e a ideologia identificadas por Morgan resistem às reformas eleitorais de $1832 \mathrm{e}$ 1867. Mais ao ponto, Samuel H. Beer (1969: 33). Neste novo discurso os setores médios passaram a ser o verdadeiro sustentáculo dos governos livres por não sofrerem "quer das compulsões da pobreza nem as tentações da riqueza".

8. Conforme o autor demonstra adiante, os Federalistas viram na ampliação do distrito eleitoral a forma de garantir que o representante se distinguisse do representado. $\mathrm{O}$ mesmo argumento pode ser encontrado em Morgan 1988.

9. Difícil resistir à observação: argumentos que tomam a consciência de classe se ancoram no mesmo paradoxo. Comprovam ser conscientes os que votam de maneira conhecida de antemão.

10. A proximidade entre o juízo liberal de Melo Franco e a interpretação marxista do populismo é por demais evidente para passar sem menção, bastando substituir a falta de autonomia do eleitor pela consciência de classe para se chegar às mesmas conclusões. Consulte-se a respeito Weffort (1989).

11. Por exemplo, o mesmo Afonso Arinos saudará a eleição de Jânio Quadros à presidência como uma prova da "magnífica maturidade do povo brasileiro para o exercício 
efetivo e não apenas formal da democracia" para no ano seguinte afirmar, ao defender a emenda parlamentarista, que o "presidente se elege arrastando uma emoção emotiva em todo o país, e cada vez mais se elegerá desta maneira porque só poderá suscitar o voto da massa nacional, nas condições em que ela atualmente vota, o candidato que estiver em condições de despertar-lhe o fervor e o entusiasmo por cima dos partidos". Ambas as passagens são citadas em Lattman-Weltman (2005:115 e 116).

12. Este não é o espaço adequado para desenvolver o ponto, mas cabe notar que a preocupação central da literatura política brasileira vai de um extremo ao outro. Não poderíamos ter democracia no Império e na Primeira República em função do controle social exercido sobre os eleitores. Na República Populista, o problema seria o inverso: disponibilidade excessiva das massas urbanas, sua relação direta com os líderes expressa na falta de necessária mediação partidária. O populismo (ou o pretorianismo) seria o vértice oposto do coronelismo.

13. A identificação do problema por meio da enumeração é prática comum entre os comentadores da obra. Por exemplo, Maria D' Alva Gil Kinzo observa: “Foi sem dúvida Nunes Leal, em sua obra publicada em 1949, quem apontou com grande propriedade os problemas do sistema representativo de então, relacionando-o a problemas estruturais do país. Segundo Nunes Leal, não podemos atribuir a fatores de ordem política apenas os defeitos de nosso sistema representativo; pelo contrário, os problemas de fraude, corrupção e governismo, ou ainda, o falseamento da representação, têm vigência na política brasileira em grande parte por se inscreverem num determinado quadro econômico e social" (1980:87; ênfases minhas). Sustento a seguir que estes três aspectos não podem ser tomados como sinônimos.

14. Natalio Botana (1994), analisando a política argentina do período 1880-1916, chega a conclusões similares: a inversão do governo representativo toma sua forma acabada quando o governo se torna o grande eleitor. Ver em especial a segunda parte do livro de Botana. O paralelismo das análises de Botana e Nunes Leal e das experiências políticas do Brasil e da Argentina pede um tratamento mais aprofundado. Consultar a este respeito Fausto e Devoto (2004:147-258).

15. Uma caracterização acabada do investimento na construção e manutenção do eleitorado se encontra na seguinte descrição: “Desde 1876 (antes, portanto, da Lei Saraiva, que institui a eleição direta), Rodrigues Alves vinha preparando cuidadosamente as suas bases eleitorais. Havendo concluído o mandato provincial, contraído casamento e se fixado na cidade natal [Guaratinguetá], possuía agora condições, inclusive tempo, para a penosa construção do prestígio político local. Nos seus arquivos existem centenas de títulos de qualificação de eleitores expedidos naquele ano, o que comprova a intenção de Rodrigues Alves de candidatar-se a em breve para a Assembleia Geral. O título de qualificação, de acordo com a eleição vigente, continha o nome do eleitor e seus qualificativos. A maioria era composta de lavradores (de fato trabalhadores rurais, sendo que numerosos eram analfabetos, o que era permitido pelo sistema de voto indireto, que então vigorava. Quando Rodrigues Alves se elegeu pela primeira vez deputado geral, para a Câmara de 1885, já existia a Lei Saraiva do voto direto. Dessa fase existe uma curiosa lista de eleitores, feita possivelmente pelo seu irmão Antônio, que documenta os costumes políticos do tempo. A lista é de 1887 e refere-se aos colégios eleitorais de Lorena e Cruzeiro. Os eleitores vêm numerados (começam com o Visconde de Pimentel) e os nomes são seguidos de anotações, que esclarecem quais seriam os votos dos eleitores. Raros são os que não votariam no 


\section{Fernando Limongi}

candidato. Alguns impõem condições, como o pagamento de transporte, ou compromissos do candidato no exercício do mandato." (Melo Franco, 1973:50)

16. Ver a este respeito Lamounier (1981:238), que afirma que mesmo o "a legalização do caciquismo" (ou do coronelismo) exigiria "alguma fórmula jurídica de caráter geral". Como nota o autor, sem esta fórmula jurídica, "o clássico problema do 'por que não eu?' se apresenta fatalmente nestas situações. Ora, esse precisamente é o problema que se apresenta, e talvez de forma mais aguda, quando se trata não de generais, mas de coronéis na acepção tornada clássica por Victor Nunes Leal: potentados provincianos envolvidos em lutas mortais pelo prestígio e pelas prebendas do poder público. Por isso é que divirjo bastante da conhecida tendência a ver nosso antigo regime liberal-represenativo como uma ideia quimérica, porque importada, 'fora de lugar': divirjo pela razão muita caseira de que vejo no 'por que não eu' o problema político por excelência, um problema de todos os lugares imagináveis."

17. "Eleições, necessariamente, devem seguir regras que regulem quem pode votar, se o voto é direto ou indireto, secreto ou público, compulsório ou voluntário; como votos são agregados e assim por diante. E regras afetam resultados (...) Portanto, eleições são inextrincavelmente manipuladas. Manipulação não é o mesmo que fraude. Manipulação consiste em estabelecer regras enquanto a fraude envolve quebrar as regras" (Przeworski, 2010:119; tradução minha).

18. Schneider (2001: 266) acompanha os julgamentos de recursos eleitorais pelo Tribunal de Justiça de São Paulo na Primeira República referentes às eleições municipais. A autora ressalta o caráter necessariamente formal dos processos, circunscritos aos aspectos legais previstos pela legislação vigente, sobretudo no que se refere às provas relativas à nulidade e fraudes praticadas nas eleições. Muitos dos processos relatados revelem não ser raro que determinados eleitores fossem impedidos de votar por meios violentos, ainda assim, "a maioria das ações envolvia problemas de incompatibilidade para o exercício dos cargos de juiz de paz e vereador, assim como disputa entre as autoridades públicas na condução do pleito e organização das Câmaras".

19. Nunes Leal, cabe notar, não é inteiramente consistente neste ponto. Há passagens em que o terceiro escrutínio é ressaltado, como, por exemplo, à página 102.

20. Ricci e Zulini (2011) mostram que as degolas e outros artifícios pós-eleitorais eram bem menos frequentes do que as alusões normalmente feitas na crônica política sobre o período.

21. A passagem se encontra na nota 37 da página 40 de Coronelismo, Enxada e Voto. Como notado anteriormente, o ponto é confirmado pelo estudo de Schneider: a violência no processo eleitoral visava justamente impedir que os eleitores da oposição votassem.

22. Quanto à primeira destas, realizada em 7 de abril de 1835, os resultados indicam grande dispersão de votos, apontando para seu caráter competitivo. Os resultados podem ser consultados em Porto (2002: 54).

23. Deve-se notar, contudo, que a Constituição de 1937 não deixou de prever eleições. Estas deveriam ocorrer após o termo do Primeiro Período Presidencial. Além disto, como mostra Angela de Castro Gomes (2005, cap. 8), Vargas e seu círculo mais íntimo formularam planos para restaurar o processo eleitoral mas assegurando-se de este não viesse a ser competitivo. A chave mestra do plano estava no controle que o governo teria sobre o alistamento eleitoral apoiado estrutura sindical oficial. Mais interes- 
sante ainda, como observa a autora, é que o projeto visava justamente neutralizar o poder das oligarquias rurais.

24. Castro Gomes (2005) representa uma exceção.

\section{REFERÊNCIAS BIBLIOGRÁFICAS}

ANDRADE, Luís Aureliano Gama. (2004), “O Município na Política Brasileira: Revisitando Coronelismo, Enxada e Voto", in L. Avelar e A. O. Cintra (eds.), O Sistema Político Brasileiro: Uma Introdução. Rio de Janeiro/São Paulo, Fundação Konrad Adenauer/Fundação Editora Unesp, pp. 205-221.

BARMAN, Roderick. (1994), Brazil: The Forging of a Nation (1789-1852). Stanford, Stanford University Press.

BENEVIDES, Maria Victória. (1981), A UDN e o Udenismo. São Paulo, Paz e Terra.

BEER, Samuel H. (1969), British Politics in the Collectivist Age. New York, Vintage Books.

BOTANA, Natalio R. (1994), El Orden Conservador. La Política argentina entre 1880 y 1916. Buenos Aires, Editorial Sudamerica.

CAMPELlO DE SOUZA, Maria do Carmo. (1976), Estado e Partidos Políticos no Brasil (1930 a 1964). São Paulo: Alfa-Ômega.

CARVALHO, José Murilo de. (2007), D. Pedro II. São Paulo, Companhia das Letras. . (1988), Teatro de Sombras: A Política Imperial. São Paulo, Vértice.

(1977), “Mandonismo, Coronelismo, Clientelismo: Uma Discussão Conceitual". DADOS, vol. 40, no 2, pp. 229-250.

CASTRO GOMES, Angela. (2005), A Invenção do Trabalhismo. Rio de Janeiro, FGV Editora.

CINTRA, Antonio Octávio. (1974), "A Política Tradicional Brasileira: Uma Interpretação das Relações Centro e a Periferia". Cadernos DCP, no 1, Departamento de Ciência Política, UFMG.

FAUSTO, Boris e DEVOTO, Fernando J. (2005), Brasil e Argentina. Um Ensaio de História Comparada (1850-2002). São Paulo, Editora 34.

HANHAM, Harold John. (1978), Elections and Party Management. Politics in the Time of Disraeli and Gladstone. London, The Havester Press Limted.

KINZO, Maria D’Alva Gil. (1980), Representação Política e Sistema Eleitoral no Brasil. São Paulo, Editora Símbolo.

LAMOUNIER, Bolivar. (1981), “Representação Política: A Importância de Certos Formalismos", in B. Lamounier, F. Weffort e M. V. Benevides (orgs.), Direito, Cidadania e Participação. São Paulo, T. A. Queiroz Editor, pp. 233-260. 


\section{Fernando Limongi}

LATTMAN-WELTMAN, Fernando. (2005), A Política Domesticada. Afonso Arinos e o Colapso da Democracia em 1964. Rio de Janeiro, FGV Editora.

LEAL, Victor Nunes. (1975) [1949], Coronelismo, Enxada e Voto. São Paulo, Editora Alfa-Ômega.

MANIN, Bernard. (1997), The Principles of Representative Government. London, Cambridge University Press.

MELO FRANCO, Afonso Arinos. (1980), História e Teoria dos Partidos Políticos no Brasil. São Paulo, Editora Alfa-Ômega (3a ed.).

. (1973), Rodrigues Alves: Apogeu e Declínio do Presidencialismo. Rio de Janeiro/São Paulo, José Olimpio/Edusp.

MORGAN, Edmund. (1988), Inventing the People. New York, W. W. Norton \& Company.

PORTO, Walter Costa. (2002), O Voto no Brasil. Rio de Janeiro, Topbooks.

PRZEWORSKI, Adam. (2010), Democracy and the Limits of Self-Government. New York, Cambridge University Press.

RICCI, Paolo e ZULLINI, Jacqueline. (2011), Eleições e Representação na Primeira República: O Processo de Verificação dos Poderes na Câmara dos Deputados. São Paulo, Universidade de São Paulo. Mimeo.

SCHNEIDER, Marília. (2007), Justiça e Política na Primeira República. São Paulo, Editora Singular.

WEFFORT, Francisco Correa. (1989), O Populismo na Politica Brasileira. Rio de Janeiro, Paz e Terra. 


\begin{abstract}
Elections and Democracy in Brazil: Victor Nunes Leal and the 1945 Transition
\end{abstract}

This article discusses the necessary conditions for a democratic government to prevail, with the study Coronelismo: the Municipality and Representative Government in Brazil as the point of departure. The article seeks to identify the book's causal explanations for the emergence of democracy, and more precisely for regimes in which governments lose elections. Why were elections not truly competitive over the course of the Empire and the First Republic? Why did they change after the fall of the Estado Novo? Nunes Leal was one of the few Brazilian authors to explicitly tackle this challenge.

Key words: elections; democratization; political competition

\title{
RÉSUMÉ \\ Élections et Démocratie au Brésil: Victor Nunes Leal et la Transition de 1945
}

Avec pour point de départ le livre Coronelismo, enxada e voto, on examine ici les conditions nécessaires à l'exercice d'un gouvernement démocratique. On s'efforce de relever les causes présentées dans cet ouvrage expliquant l'émergence de la démocratie et, plus précisément, des régimes sous lesquels des gouvernements échouent aux élections. Pourquoi les élections n'ont-elles pas été de vraies compétitions au long de l'Empire et de la Première République au Brésil? Pourquoi leur nature a-t-elle changé après la chute de l'Estado Novo? Nunes Leal est l'un des rares auteurs brésiliens à avoir relevé ce défi.

Mots-clés: élections; démocratisation; compétition politique 